\title{
Investigating Omani Artisans' Skills in Marketing their Creative Manufactured Goods
}

\author{
Dr. Badar Mohammed Almamari"
}

Sultan Qaboos University, Al Khoudh, Muscat 123, Oman

DOI: $\underline{\text { 10.36348/sjhss.2020.v05i09.001 }}$ | Received: 17.08 .2020 |Accepted: 25.08 .2020 | Published: 03.09 .2020

*Corresponding author: Dr. Badar Mohammed Almamari

Abstract

Although there are 12 branches of the Omani Craftsman House $(\mathrm{OCH})$, which is considered by the Public Authority for Crafts Industries (PACI) and its associated enterprises to be the official retailer for marketing Omani traditional crafted products (PACI, 2019), it is not clear if the authority has given priority to considering craftsmanship in Oman as a business. Craft people's marketing and business skills have long been of great interest in a wide range of art and craft fields. The main aim of this study is to investigate the importance of increasing the ability of Omani craftspeople to market their craft products at local markets.

Keywords: Crafts, Marketing skills, Omani Craftsman House (OCH).

Copyright @ 2020: This is an open-access article distributed under the terms of the Creative Commons Attribution license which permits unrestricted use, distribution, and reproduction in any medium for non-commercial use (NonCommercial, or CC-BY-NC) provided the original author and source are credited.

\section{INTRODUCTION}

There is a growing body of literature that recognizes the importance of craftsmanship and of developing craft industries as medium and small enterprises internationally. Some researchers have provided excuses for craftsmen/women as to why they pay less attention to business and marketing, arguing that this is because they believe that it is hard to justify or understand the small enterprise growth process [1]. This notion was supported by Deakins and Freel [2] when they concluded their study: "we are still a long way from understanding the dynamics of [the] growth process and entrepreneurial developments in small firms" (p.154). Being a business craftsman/woman is not a simple idea, and it is considered to be a weakness in terms of crafts in many countries around the world, and this occurs because the craftsman/woman himself/herself is not properly prepared as a "business minded" person [1]. McAuley and Clarke [1] added that "those seeking growth [in craft enterprises] identify themselves as being a business person or are happily combining the crafts and business role" (p.27). Also, being a businessman/woman and craftsman/woman at the same time is not a trouble-free idea because dealing with crafts means dealing with other issues, like identity and social contexts. In her article 'Craft and Social Identity', Cathy Lynne Costin [3] emphasized that "artisans and consumers must accept, create and negotiate the social legitimacy of production and the conditions of production and distribution, usually defined in terms of social identity" (p.3).

Craftsmen/women's negative attitudes towards concepts such as marketing and business form a barrier between them and their consumers, and the most recognizable reason for this attitude is that craftsmen/women always want to be considered as artists and designers rather than as artisans [4].

Omani craftsmen/women are classified in this artisan category, and this truth is easily recognized when we look at art associations or societies, places which largely ignore craftsmanship. Most of the above studies about craftspeople's skills in marketing ignored that a craftsperson must sometimes market his/her crafts personally, without any support such as that which the PACI offers. In Oman, over the past decade the Public Authority for Crafts Industries (PACI) has played a strong role in supporting the traditional ceramics industry [5]. So, regarding this part of the research, the researcher will investigate the role of the Omani Craftsman House (the PACI official retailers) in craft marketing in Oman.

\section{Shortage of Individual Craft Marketing Skills}

This part of the data collection (interviews) was designed to investigate crafts people's ability to market their crafts, particularly when they are separated from the PACI and its financial support. So, 
craftspeople were the major part of the sample of this data collection, but also the participating executive in the Department of Marketing at the PACI headquarters was interviewed in order to cover the required data for this subject. Interviewees were selected very carefully for this part as the researcher preferred to meet craftspeople who had a real connection with the $\mathrm{OCH}$, and who were attached to their relevant craft centers, such as the Weaving Training and Producing Center (WTPC) and the Silk Weaving Training and Producing Center (SWTPC). The arguments extracted from published resources led to an understanding of the role of a craftsperson in the marketing stage. Consequently, questions regarding this subject were generated from the published arguments that were mentioned in the literature, in consideration of Omani economic, social, and special cultural conditions.

For some participants, Omani craftsmen/women did not see themselves as businessmen/women in their areas. As the statistics collected by the researcher through the interviews conducted between 2010 and 2019 showed, each craftsman/woman who attended any of the PACI crafts training enterprises earned 300 OR. This led craftspeople to see these enterprises like other government recruitment institutions (occupations), from where they received a monthly fixed income (salary). According to some participants of both the WTPC and SWTPC, this led craftspeople to work in the enterprises with less motivation and affected their creativity negatively (quality), and it also impacted on the number of objects they made per day (quantity). It seemed to be very disappointing that the PACI did not pay attention to increasing the tendency for craftsmen/women to create their own businesses or at least concentrate on the idea of "craft as business" as mentioned by the participants.

After the researcher showed the participants that the PACI used methods of 'giving monthly salaries' and of 'marketing crafts via the $\mathrm{OCH}$,' he asked them to give their opinions about these methods. Participants asserted that some negative consequences could occur through the use of these methods, especially for independent craftspeople (non-PACI craftspeople). They believed that the abovementioned methods would only serve a small quantity of craftspeople and that independent craftspeople would not be able to take advantage of these methods.

In fact, both strategies, 'giving salaries' or 'marketing produced crafts via the $\mathrm{OCH}$,' need to be investigated in the next part of this research, and if these two strategies are not seen to be alternatives for developing the marketing skills of craftspeople, then, in the future, these skills will need to be developed to allow craftspeople to market their crafts individually.
Special Findings: Omani Craftspeople Do Not See Themselves as Businessmen/women in the Local Market

The increasing exchange of traditional craft items in world markets has had a deep impact on the lives of the craftspeople that produce them [6]. As established in the previous part of this paper, participants concentrated on two main arguments regarding the issue of non-businessmen/women craftspeople in the PACI craft centers. First, the Omani craftspeople in the authority centers receive a small amount of money monthly while attending training programs in the PACI centers, and this stable payment has led craftspeople to be less concerned about their marketing duties and skills. Second, the establishment of several branches of the Omani Craftsman House $(\mathrm{OCH})$ and the centers' revenues for marketing the authority centers' products have driven local craftspeople to believe that the marketing role has become part of the PACI's duties and that the craftspeople's role should only be during the craft production stage.

No doubt that the reason for giving stable wages to craftspeople was to encourage them to be involved in this area of culture, especially in the early days of the establishment of the authority (PACI). But 17 years after its establishment, the 'monthly incomes system' may be causing other negative consequences. The privilege of being given monthly salaries is extremely limited to only those craftspeople who are recruited by the PACI craft centers, so other craftspeople, who work as individuals are excluded from this advantage. This is because the craft centers in the PACI have limited space to employ craftspeople. Also, the salary system may impact negatively on 'private craft marketing skills' as the majority of those in craft industries would prefer to earn permanent governmental salaries, rather than facing the market risks of the private craft sector. Moreover, full-time craft jobs at the PACI result in less competition in the Omani local markets, in general, and also between craftspeople. This has led to a reduction in the quality of crafts (artistic, aesthetical, and intangible heritage values), on one hand, and has reduced the variety of exhibited craft goods on the other. The permanent salary system has also helped to increase the role of the middleman as a stakeholder in the marketing process, as an alternative to the marketing of the crafts by the craftspeople themselves. This has increased the prices of craft products locally and internationally, and, consequently, this could impact on society's demand for and the consumption of crafts in general. Middlemen craft retailers could also have a cultural effect on the craft industry because they have less experience with marketing cultural and creative goods. All the above predicted consequences of the absence of businessmen/craftsmen and businesswomen/ craftswomen are not a reason to stop the permanent salary system, but the PACI has to, at least, re-examine 
its strategy of 'monthly salaries' to address its negative impacts in the craft industry.

If truth be told, the $\mathrm{OCH}$ has reduced marketing risks for individual craftsmanship, but craft revenues represented in $\mathrm{OCH}$ style could cause the death of the 'craftsman as an entrepreneur' style locally in Oman. In their book The Enterprising Man, Collins, Moore, and Unwalle [7] defined entrepreneur craftsmen/women as "individuals who follow in the footsteps of family relations or role models who gave them early exposure to the craft they decide to follow as an entrepreneur" (p.84). And similar to them, Hornaday [8] described entrepreneur craftspeople as individuals who supply a product directly to customers face-to-face and who generally enjoy this social interaction with society and people. In fact, because of the new revenues of OCH style, the social and cultural communication between craftspeople (intangible heritage makers represented in Traditional Craftsmanship) and their society's people (intangible heritage appreciators and consumers) has disappeared in Oman.

Furthermore, the $\mathrm{OCH}$ style of marketing crafts can be considered to be an alternative to the shortage of craft marketing festivals, 'craft village' styles, and souvenir stores. This could be enough reason to encourage the support of the $\mathrm{OCH}$ as a style of marketing. Because the $\mathrm{OCH}$ was established as an alternative to 'craftsman entrepreneur' style, the total profits of the $\mathrm{OCH}$, when divided between the total numbers of craftspeople who supply the $\mathrm{OCH}$, cannot satisfy both the authority and the craftspeople. For example, when we divided the total profits of all the $\mathrm{OCH}$ by the number of makers (registered craftspeople) who worked in all the authority's craft centers in the same year as the data collection, we calculated that each craftsperson would only have earnt a small amount of money that year. This asserts that the $\mathrm{OCH}$ cannot be an alternative to the 'craftsman entrepreneur' because of the low profits earned by each craftsman/woman annually.

\section{An Additional Finding: Lack of Access to Marketing Information}

In the capacity-building crafts enterprise framework (UNESCO), Kamara [9] considered that some types of information must be available for craftspeople compulsorily, in order to pave the way for individual artisans in craft enterprises to market their crafts smoothly (p.40). The PACI used its website as the main source for craftspeople and consumers seeking information. One major drawback of this approach could be that some craftspeople have less access to internet services, so they will not be able to take advantage of website data. Another serious weakness with the website method, however, is that for those craftspeople that live in remote areas, sometimes internet services are not available at all.
Research participants expressed their concerns about the limited access to information. Most of the interviewees felt that the PACI did not provide real and useful information for craftsmen/women; their interviews revealed specific information regarding this issue. They asserted that the PACI did not provide enough information. They complained about the shortage of published statistics, for example, and the participating supervisor mentioned that the PACI needs to provide more details about local people's demands, and a participant asserted the importance of providing information about technical developments in order to elevate craft products to meet the market demand.

The majority of the PACI headquarter interviewees thought that even educated craftspeople showed some carelessness in seeking information and that the problem was not about the availability of information. They asserted that the PACI website and the authority's main branch doors are open all the time, but it is hard to provide information on all craft issues rather than the issues of marketing and craft consumption alone.

The first serious discussions and analyses of access to information in the craft field emerged in 2003 and were initiated by Karama, as shown in the literature review. In order to analyze the capacity-building crafts enterprise framework, created by UNESCO, Karama asserted the importance of information access in craft industries and identified the types of information required by craftspeople in this field.

As also shown in the Capacity-building for Cultural Enterprises in Developing Countries' framework, when the author asserted that the foremost market weakness in small enterprises, such as craft firms, was the lack of information in general and the lack of market information in particular [9], the research participants concentrated on 'accessing information' but paid less attention to the types of information usually needed in craft marketing in general and in Oman in particular.

In the capacity-building framework, Kamara considered that some types of information must be available for craftspeople compulsorily to pave the way for individual artisans in craft enterprises to market their crafts smoothly. These types of information covered market trends, competitors' production, the craft market's characteristics such as marketing place and times, distribution channels such as festivals and craft fairs, and financial services' support locally and internationally in the case of exporting [9].

Craftsmen/women in the PACI craft centers receive this information through two methods. The first method is the direct connection with the main office of the authority and, for the craftspeople in each center, through the center's supervisor. The second method of 
obtaining information is via the official website of the authority. So, when educated craftspeople are absent, the supervisor will be the only way of linking artisans with the main office of the PACI for them to obtain useful information. Even though some craftspeople are educated, their education does not necessarily mean that they are qualified to use technology (e.g., the internet) to seek information. In addition to this, the unavailability of high-quality internet services in some areas (e.g., rural territories) in Oman made the website method less useful. In other words, if the supervisor is not prepared well enough to act as a link between artisans and the authority, the lack of 'information access' will significantly harm craft marketing.

The PACI official website was not created only to market the authority's craft production. It was built to provide general information about Omani crafts, events, conferences, publications, the authority-related centers, new regulations and announcements, some statistics (mostly not updated), and news (www.paci.gov.om). Also, it is recognizable that there is no information regarding intangible cultural heritage knowledge and skills, which could at least draw craftspeople's attention to this aspect of their traditional craftsmanship. In other words, there is an actual shortage of information regarding two major areas on the official website: craft marketing and traditional craftsmanship's intangible cultural heritage.

\section{CONCLUSION AND \\ RECOMMENDATIONS}

To conclude this study, it is very important to mention that the $\mathrm{OCH}$ and craft centers' revenues cannot provide a complete alternative to the 'craftsman entrepreneur' unless the authority reinvestigates these styles of marketing and re-explores their weaknesses to develop their efficiency in the future. Also, regarding developing the PACI website contents, this website can contribute by providing more technical information (material stores and discounts) and a video library (pottery firing techniques such as raku and crystalline glazes), by adding links to individual craftspeople's blogs, by connecting craftspeople with studio craft artists (such as art and design department staff), by giving space for craftspeople to connect with each other (through website forums), by providing contact with the society (by establishing a mailing list through the website), and by using more professional images (a website gallery). Finally, if the mail delivery system in Oman becomes well organized, the website can be developed to sell craftspeople's products through ebusiness marketing and, most importantly, through adding craftspeople's Instagram, Facebook, and Twitter pages as links for the public.

\section{REFERENCES}

1. McAuley, A., \& Clarke, P. (2009). Growing the Micro-Enterprise: Observation from the Crafts Sector, Journal of Research in Marketing and Entrepreneurship, 11(1), 22-31.

2. Deakins, D., \& Freel, M. (1998). "Entrepreneurial learning and the growth process in SMEs", The Learning Organization, 5(3), 144-15.

3. Costin, C. (1998). Introduction: Craft and Social Identity. Archeological Papers of the American Anthropological Association. 8(1), 3-16.

4. Fillis, I. (2004). The Internationalizing Smaller Craft Firm Insights from the Marketing/Entrepreneurship

Interface. International Small Business Journal. 22 (1), 57-82.

5. Almamari, B. M. (2017). Imported Traditional Pottery: Methods of Overcoming the Challenges for Traditional Ceramics Industries in Oman. Humanities and Social Sciences, 5(1), 1.

6. Nash, J. C. (2019). Crafts in the world market: the impact of global exchange on Middle American artisans. Albany, NY: State University of New York Press.

7. Collins, O. F., Moore, D. G., \& Unwalla, D. B. (1964). The enterprising man. East Lansing: Bureau of Business and Economic Research Michigan State University.

8. Hornaday, R. W. (1990). Dropping the e-words from small business research: An alternative typology. Journal of Small Business Management. Journal of Small Business Management, 28(1), 22-33.

9. Kamara, Y. (2003). Keys to Successful Cultural Enterprise Development in Developing Countries, UNESCO, Paris. 